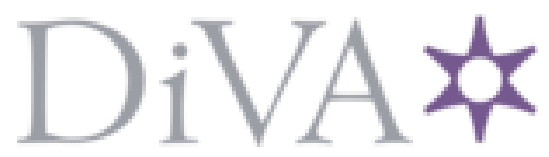

http://www.diva-portal.org

This is the published version of a paper published in African American Review.

Citation for the original published paper (version of record):

Holmgren Troy, M. (2016)

Chronotopes in Harriet Jacobs's Incidents in the Life of a Slave Girl.

African American Review, 49(1): 19-34

Access to the published version may require subscription.

N.B. When citing this work, cite the original published paper.

Permanent link to this version:

http://urn.kb.se/resolve?urn=urn:nbn:se:kau:diva-41951 


\section{PROJECT MUSE*}

\section{Chronotopes in Harriet Jacobs's Incidents in the Life of a Slave Girl}

Maria Holmgren Troy

African American Review, Volume 49, Number 1, Spring 2016, pp.

19-34 (Article)

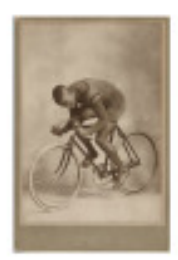

Published by Johns Hopkins University Press

DOI: 10.1353/afa.2016.0006

$\Rightarrow$ For additional information about this article

http://muse.jhu.edu/journals/afa/summary/v049/49.1.troy.html 


\section{Chronotopes in Harriet Jacobs's Incidents in the Life of a Slave Girl ${ }^{1}$}

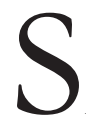

everal incisive explorations revealing how nineteenth-century African

American writing constructs time, space, and race have been published over the past few years. For example, focusing on how the "built environment" and "architectural imaginations" in the U. S. have been shaped by race, William Gleason suggests in Sites Unseen: Architecture, Race, and American Literature that "[s]tories rooted in specific places and housed in particular structures can tell us a great deal not only about past practices but also about meanings and ideologies, both shared and contested" (2). He argues, moreover, that by the mid-nineteenth century "representations of built space had become indispensable features of the literature of slavery in both the North and the South" (54). Whereas Gleason extends the interest in space and place that was ubiquitous in late twentieth-century theory and criticism, Daylanne K. English and Lloyd Pratt highlight the conceptualization of time in African American narratives. In Each Hour Redeem: Time and Justice in African American Literature, English maintains that time is as important as space and that "time, justice, and the written word are deeply intertwined" at the very center of the African American literary tradition $(4,1)$. African American writers show that "time and justice — although often imagined to be standard and uniform-are actually contingent and unevenly available: in other words, they are political fictions" (English 24; original emphasis). Multiple and conflicting experiences of temporality, Pratt explains in Archives of American Time: Literature and Modernity in the Nineteenth Century, were characteristic of modernity in the early national and antebellum United States. These experiences and understandings of time were at least partly related to the use of ancient, classical, and emergent literary genre conventions, which he argues led to "the near collapse of processes of national and racial formation" in a period that has habitually been associated with the opposite development $(3,4)$. Indeed, Pratt reframes the literary genres he discusses "as complex archival forms and as actors in the realization of America's modernity" (14). One of these genres, and one which Pratt suggests represents multiple temporalities (23), is what he calls the "African American life narrative," which includes Frederick Douglass's and Harriet Jacobs's narratives.

The question of genre has bedeviled Jacobs's narrative. In a 1981 article published in American Literature, Jean Fagan Yellin announced that "Incidents in the Life of a Slave Girl: Written by Herself has just been transformed from a questionable slave narrative into a pseudonymous autobiography . . . by the discovery of a cache of her letters" ("Written" 479). ${ }^{2}$ To a certain extent, the questions regarding the narrative's authenticity that had riddled the history of Incidents before Yellin's article and her subsequent 1980s' publications had to do with the novelistic strategies that Jacobs used rhetorically to reach, negotiate with, and convince an audience of antebellum white middle-class women in the North that her narrative was authentic. One narrative strategy that deserves more critical attention is the way in which Jacobs represents various places with varying temporalities: houses in the small town in the South, the plantation outside the town, the garret in which Linda spends almost seven years, and Philadelphia, New York, Boston, and England. 
Here I use one of Bakhtin's major concepts, the chronotope, to examine how Jacobs depicts the interaction of these places, their temporalities, and the values that accrue in and around them in order to convey Linda Brent's story and her urgent political message to her contemporary audience. I propose that employing the notion of the chronotope in an analysis of Incidents highlights the intricate ways in which the narrative both invokes and critiques the domestic as a gendered middleclass ideology centered in the home and as a sense of a unified and democratic nation. The multifaceted nature of the literary chronotope makes it particularly useful when dealing with Incidents, which draws on and has been classified as belonging to multiple genres:

In the literary artistic chronotope, spatial and temporal indicators are fused into one carefully thought-out, concrete whole. Time, as it were, thickens, takes on flesh, becomes artistically visible; likewise, space becomes charged and responsive to the movements of time, plot and history. This intersection of axes and fusion of indicators characterizes the artistic chronotope. (Bakhtin, "Forms" 84)

The chronotope operates on several intra- and intertextual levels, and it carries or embodies ideology. Bakhtin emphasizes that to the literary chronotope "belongs the meaning that shapes narrative" and that "it is precisely the chronotope that defines genre and generic distinctions" $(250,85)$. In the novel, which Bakhtin describes as "a large fiction influenced by biographical models" (130), the family house with its biographical temporality appears to be one of the most important chronotopesperhaps the most important. Intimately linked to history, the chronotope expresses a world-view, and "determines to a significant degree the image of man [or woman] in literature as well" (85); characters constitute and are molded by the chronotope in having particular ideologically charged views of, and relations to, time and space. Chronotopes, Bakhtin argues, tend to interact in dialogical ways: "Within the limits of a single work ... we may notice a number of different chronotopes and complex interactions among them" (252). This is evident in Incidents, where chronotopes often are embedded within each other or enter into contradictory, oppositional, or strained relationships.

It is by using chronotopes in her narrative, I suggest, that Jacobs levels her critique of antebellum American society, and it is through the grandmother's house as chronotope in particular that she establishes a site of negotiation with her most obvious historical addressee: the Northern white middle-class woman. ${ }^{3}$ Indeed, the grandmother's house represents a number of values that this addressee would have recognized and most likely endorsed, while at the same time it is a site of arbitration and revision of issues concerning race, class, sexuality, nationality, and gender. I return to the addressee at various points throughout my examination of chronotopes in Incidents.

Jacobs's narrative, I would argue, is not entirely linear. Although linear temporal movement permeates Linda's narration of her life and the text references countless temporal designations - years, months, weeks, days, hours - the word "incidents" in the title indicates a disrupted, fragmentary experience, one that cannot be represented as a steady progression through linear calendar time. ${ }^{4}$ The temporal fragmentation reflects the fashion in which slave families are repeatedly broken up, while the plantation slave's year follows a clearly cyclical pattern, leading to an annual disruption of an already precarious existence (Jacobs 25). The numerous examples of white male slaveholders' sexual abuse of female slaves also take on a cyclical character. According to the narrative, by the time a slave girl is about fifteen years old she is likely to have been sexually exploited by white men, abuse that will be repeated generation after generation as long as the slave system remains in place. Here Incidents seems to share in Bakhtin's critique of temporal cyclicality, seemingly reflecting his 
argument that cyclicality serves as an obstacle to "forward impulse" or development ("Forms" 209-10). In Incidents, however, the temporal cycles are not tied to purely cosmological, "natural" time as they are in Bakhtin's pre-class folkloric communities. Instead, this temporality imbues the legislation, economy, and entire ideology of the slave system in a circular repetition of abuse and oppression of one group of people by another. In Jacobs's narrative, this oppressive cyclicality blocks not only the "forward impulse" in the lives of individual slaves but also that of African Americans as a group, and, ultimately, of the whole American nation. In what follows, I discuss four chronotopes within this larger chronotope of slavery in the United States: Dr. Flint's house, the provincial town, the grandmother's house, and the garret.

\section{No Gothic Castle: Dr. Flint's House}

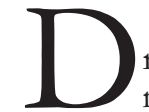

r. Flint's house is the site of Linda's exposure to the relentless sexual harassment of slavery. She belongs to Flint's daughter, and the doctor first stalks Linda in the Flint domicile. The depiction of the house itself, "a fine residence" (25), includes few if any physical details, and conveys a diffuse sense of temporality. Linda's reaching the age of physical maturity that makes her sexually attractive in the doctor's eyes is the only important temporal distinction. Even the beginning of Dr. Flint's harassment is temporally blurred: Linda is either fourteen or fifteen $(28-29,44)$.

In many respects Incidents in the Life of a Slave Girl is a narrative of continuous sexual harassment, but Linda goes far to keep her story from turning into a narrative of sexual abuse. When Dr. Flint begins harassing Linda, she describes her response in terms of war: "The war of my life had begun; and though one of God's most powerless creatures, I resolved never to be conquered" (31). Investigating contemporary narratives of slavery in light of the theories of black subjectivity they offer, Arlene R. Keizer points out that the figure of "the black slave in rebellion against white domination is the prototype for a black resistant subjectivity, a founding model of African American and Afro-Caribbean subjectivity" (9). Thus, since the 1960s, "black writers have begun to represent slavery in order to explore the process of self-creation under extremely oppressive conditions" (11). Jacobs's Linda Brent obviously stands as one of the "Ur-figures" for these writers' theoretical and aesthetic endeavors.

As for the materiality of the house, sometimes it seems as if there are not even walls, as the synecdoche of the roof for the house does considerable work in Jacobs's narrative. Although "roof" usually indicates "shelter," Linda uses it ironically to underline her unsheltered position in Dr. Flint's house: "I was compelled to live under the same roof with him-where I saw a man forty years my senior daily violating the most sacred commandments of nature" (44-45). At first, the presence of Linda's Aunt Nancy prevents the doctor from harassing Linda at night. The doctor's stratagems for removing her from Aunt Nancy's protection raise Mrs. Flint's suspicions, but when Linda tells her what she has experienced for over a year her situation improves very little. Mrs. Flint moves Linda to a room next to her and watches over her at night: "Sometimes I woke up, and found her bending over me. At other times she whispered in my ear, as though it was her husband who was speaking to me, and listened to hear what I would answer" (54). Her resentment actually makes Linda fear for her life. While Linda can see through Dr. Flint's machinations and even pity his wife, Mrs. Flint shows no empathy for Linda's predicament, but is instead driven by jealousy and misdirected suspicion to perpetuate the doctor's harassment and threats. 
Mrs. Flint's behavior indicates that the chronotope of Dr. Flint's house lacks a moral and emotional center that the wife should have provided according to the conventions of the cult of domesticity, to which the Northern white female addressee presumably subscribed. Thus, in providing very few physical details of the house and in depicting Mrs. Flint as cruel, unsympathetic, and morally deficient, the narrator bars the addressee's identification with her. Such identification could otherwise have been possible since the white female reader and Mrs. Flint have race, class, and gender in common. Instead, the depiction of Mrs. Flint's behavior serves to elicit sympathy for the persecuted slave girl and, by extension, other slave girls in similar situations.

The diffuse sense of temporality in and the lack of physicality of Dr. Flint's house as chronotope can be read as a sign of Jacobs's desire not to lend this dwelling a gothic sense of time. As Teresa A. Goddu argues, Jacobs works "within and against an antebellum discourse that gothicizes slavery" (132). Indeed, Jennifer Rae Greeson, who reads Incidents in the context of the nineteenth-century American urban gothic genre, persuasively argues that Jacobs uses conventions from this genre to reach Northern readers and to lend greater national political significance to her narrative. Greeson points out that "while the most immediate generic missions of urban gothic and abolitionist narrative differed — with one attempting to fathom the Northern city, the other calling for an end to Southern slavery-perhaps their most enduring political impact on U.S. culture was their joint positing of the sexual exploitation of women as evidence of the ills of U.S. society" (278-79). Goddu also shows convincingly how Jacobs and other African American writers negotiate and revise gothic conventions in order to describe an unspeakable contemporary situation or history. She explains, too, how the gothic threatens to "dematerialize and displace" what it represents: "This displacement of event by effect also tends to relocate the horror of slavery from the slave's experience to the white viewer's response" (134); and she suggests how these processes work in temporal terms. When an event is translated into a gothic symbol, she asserts, it is "displaced into the future and translated into a legend" (134). Claiming that Incidents follows a "typical female gothic plot," however, Goddu mistakes Dr. Flint's house in town for the plantation where his son lives: "Imprisoned in a plantation (read castle) that is cut off from the laws of the outside world, [Linda] finds herself at the mercy of a lascivious villain, her 'persecutor,' Doctor Flint" (189-90n24). ${ }^{5}$

I would argue instead that Jacobs did not want the addressee to "read castle," which is a good reason for Linda's not describing the doctor's house in greater detail, and why she does not make it appear gothic in any sense, even if its inhabitants are described in gothic terms; as Greeson also observes, the vocabulary used to describe the inhabitants of Dr. Flint's house comes from urban gothic novels and "Northern newspaper accounts of urban procurers" (293). Linda saves her gothic architectural vocabulary for the crawlspace in which she spends seven years. As a chronotope, according to Bakhtin, the gothic castle is "saturated through and through with a time that is historical in the narrow sense of the word, that is, the time of the historical past" ("Forms" 245-46). Contrary to Goddu's explanation of the temporality of the gothic, then, using the gothic castle, or a modification of it, in the narrative would risk displacing the location and events not into the future, but into the distant past. Representing a site of the wrongs still committed against slave women at the time when the narrative was written and published, it is important that Dr. Flint's house is located in the narrative present and not in a remote historical past. 


\section{The Provincial Town}

Ir he doctor's house is set in a small town. As I illustrate here, Bakhtin's observations on the "petty-bourgeois provincial town with its stagnant life," which is a prevalent chronotope in nineteenth-century novels, are pertinent in this context. The temporality of the chronotope of the "Flaubertian" town that Bakhtin discusses is "cyclical everyday time" ("Forms" 247). He describes the time of such a provincial town as eventless, which makes it almost motionless; "therefore it cannot serve as the primary time of the novel." As an "ancillary time" it can instead function "as a contrasting background for temporal sequences that are more charged with energy and event" (248). Accordingly, Linda becomes aware of "the stagnation in our Southern towns" when she contrasts it with the "tide of life," the temporal pace, in Philadelphia and London (Jacobs 247, 276). What Linda experiences here is a sense of modern time. As English points out, "African American writers have not always represented time and its measure as oppressive; modern time and timekeeping often appear as objects of desire in both early and modern African American texts" (37). In both Philadelphia and London, Linda's comment on the "tide of life" comes at the moment when she, as protagonist, considers herself free from slavery. We can therefore also see the stagnation in the Southern town as caused by the antebellum American system of slavery, the temporality of which is fragmentary and cyclical, as outlined above. It is, however, important to realize that the Southern provincial town as chronotope in Incidents is not simply Dr. Flint's house as chronotope on a larger scale. The two chronotopes exist in a state of tension and opposition.

It is precisely because Dr. Flint's house is embedded in a small town that he refrains from openly using his power to force Linda to submit to him: "Bad as are the laws and customs in a slaveholding community, the doctor, as a professional man, deemed it prudent to keep up some outward show of decency" (47). Thus, the doctor keeps up a façade of propriety — a propriety absent in his own housein order not to alienate his neighbors and clients in the small town. Linda expresses her gratitude for the small-town surveillance and the townspeople's knowledge of other people's affairs more than once in her narrative $(47,55)$. The respect that the townspeople, black and white, have for her grandmother also helps her, even though her own respect, which borders on "awe," makes her reluctant to tell her grandmother about the doctor's persecution (46).

Similarly, it is in this small-town context that Linda's grandmother gains her freedom by making public Dr. Flint's betrayal when her mistress dies. Dr. Flint ignores her mistress's will, which frees Linda's grandmother, and tells her that he has to sell her. He also tells her that he does not want to "wound her feelings by putting her up at auction, and that he would prefer to dispose of her at private sale" (20). Linda's grandmother sees through the doctor's hypocrisy; instead of letting him save face, she springs upon the auction block and publicly exposes the doctor's dishonesty and greed to the small-town community. An old white lady who has known her for a long time buys her for the insignificant sum of fifty dollars and gives the grandmother her freedom, while the other people at the auction respect the old lady's bid as well as her intentions. The provincial town as chronotope, then, represents a kind of substitute, however inadequate and faulty, for legal protection for its African American inhabitants, enslaved and free.

Dr. Flint unsurprisingly works hard to remove Linda from the protective network of the town. He tells her that he will build a small house for her "in a secluded place, four miles away from the town" (82). For Linda, who knows that she depends on the protection of the small town, including her kin's protection of her, this is a worst-case scenario. She recognizes his wish to separate her from the town and to contain her in an isolated place where he would have unhampered sexual access to her. 
Yet Dr. Flint's attempt to architecturally appropriate and contain Linda's sexuality actually accomplishes the very opposite of what he has in mind. The thought of being removed from the protection of the provincial town makes Linda desperate, and she begins a sexual relationship with another white man, Mr. Sands. She does this partly to enrage Dr. Flint, and in the hope that Mr. Sands might buy her from the doctor and set her free. ${ }^{6}$ When Dr. Flint tells her that the cottage is completed, Linda replies, "I will never go there. In a few months I shall be a mother" (87). The doctor, however, does not give up his plan to make Linda his concubine and renews his offer of a cottage after she has had another child by Mr. Sands (127). She is acutely aware that the offer is only a way for Dr. Flint to gain power over her. The doctor follows up his proposition with a threat to send her and her children to his son's plantation (128). Although Dr. Flint's son is "a chip of the old block" (132), Linda regards the plantation as the better of two horrifying alternatives, both of which will locate her outside the protection of the provincial town.

\section{The Grandmother's House: Class, Community, Family}

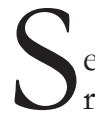

et in the same small town, the grandmother's house is situated near Dr. Flint's residence. Linda's grandmother acquires the house after her manumission: "By perseverance and unwearied industry, she was now mistress of a snug little home, surrounded with the necessaries of life" (28). ${ }^{7}$ I suggest that the grandmother's work ethic_- "perseverance" and "unwearied industry" — underlies the values that her house as chronotope embodies, and that it is significant to the Northern addressee, who would have recognized and treasured these traits. Although Linda describes the house as "little" it is far from being a cabin; it is a two-story house with a number of rooms. That it is or comes very close to being the middle-class dwelling that was and still is the American norm is shown in chapter twelve, "Fear of Insurrection." The chapter was developed at the request of Jacobs's Northern editor Lydia Maria Child, ${ }^{8}$ which may partly explain the careful depiction of the grandmother's house as a chronotope representing middle-class values, and as a site of identification for the addressee.

This chapter, which describes the measures taken by white residents in the town after Nat Turner's rebellion in 1831, emphasizes the importance of the location of the house, highlighting the class of the house and its inhabitants in the confrontation with and intrusion of "country bullies and the poor whites" (97). ${ }^{9}$ The chapter establishes the grandmother's house as an American middle-class abode complete with material comforts and cultivated inhabitants set off in stark contrast to the intruders, their behavior, and, by implication, their dwellings (100-02). During the search for insurrection plans, "[c]olored people and slaves who lived in remote parts of the town suffered in an especial manner." Their dwellings, "unless they happened to be protected by some influential white person, who was nigh at hand, were robbed of clothing and every thing else the marauders thought worth carrying away" (98-99). Linda's remark- "What a spectacle was that for a civilized country! A rabble, staggering under intoxication, assuming to be the administrators of justice!" (102)ties this domestic violation directly to the nation and its claim to justice, democracy, and civilization. The search is not called off until the drunken search parties actually threaten the property of the white people in the town: "They rallied the drunken swarm, drove them back into the country, and set a guard over the town" (102). By extension, the intrusion into the grandmother's house, as well as the ultimate danger to white people's homes, can profitably be read as a threat directed toward the middle-class values and home of the Northern addressee. ${ }^{10}$ 
In an ironic twist, then, the title of the chapter, "Fear of Insurrection," ultimately references the fear of insurrection on the part of the poor white lower-class search parties that form an uncontrollable mob threatening domestic security, and, as Carla Peterson observes, "this description serves the important political function of inverting racial and social hierarchies" (159). Andrew Levy, in contrast, claims that Jacobs "invokes class fears, but severs the connection between race and class: her appeal to the fear of a lower caste insurrection is as conservative as her displacement of race from that fear is radical" (214). I would argue, however, that Jacobs's treatment of class in relation to race is more complicated. At one point in Incidents, Jacobs uses the phrase "lower class" to describe black people: "Every child rises early on Christmas morning to see the Johnkannaus. Without them, Christmas would be shorn of its greatest attraction. They consist of companies of slaves from the plantations, generally of the lower class" (179-80; emphasis added). It is enlightening to read, in the chapter "Christmas Festivities," about these well-rehearsed, sober companies of slaves carrying out an artistic and religious African ritual ${ }^{11}$ and compare them to the white search parties in "Fear of Insurrection." The class conservatism that Levy sees in Incidents may indeed be strategic and contextual since Jacobs represents the black lower-class Johnkannaus companies in exclusively positive terms.

The white lower-class search party's intrusion into the grandmother's house causes some damage, but as Linda somewhat ironically states, "[w] came out of this affair very fortunately; not losing any thing except some wearing apparel." Leaving the house the search party also destroys the garden, and the captain pronounces a "malediction on the house. He said it ought to be burned to the ground, and each of its inmates receive thirty-nine lashes" (102). The household avoids further harm due to its black inhabitants' agency and its location in and relation to the small town. Jacobs again stresses the importance of the provincial town as a source of protection, however tenuous, for black people under slavery; Linda asks a "white gentleman who was friendly" to them to "have the goodness to come in and stay till the search was over," which he does (99-100). However, Linda also makes it very clear that it is the white citizens of the town who initiate the search and consequently unleash the lower-class white mob. The need for white male protection is not very remarkable in this nineteenth-century middle-class setting, but the passive role that the protector plays marks a departure from "normal" middle-class conditions: according to Linda's depiction of the event, the white gentleman neither acts nor utters a word during the search. The male white protector's passivity and inaudibility make the female black inhabitants' agency and articulate verbal ability-both the grandmother's speech and the narrator's representation of the event-more distinct.

"Fear of Insurrection" partly illustrates the openness of the grandmother's house, which works in two directions. To begin with, in spite of its comforts, because it belongs to a black person and is situated within the system of slavery, the house is not safe; it is permeable and open to intrusions. ${ }^{12}$ Nevertheless, it is a place of sustenance and friendship for both black and white, and shelters a number of people.

The grandmother's house is undoubtedly a source of sustenance for the entire community of the small town. The large oven is the central feature, and Linda's grandmother provides the town with crackers and preserves, which is also her way of making money. Doing this, she combines the (male) public roles of homeowner, moneymaker and provider with the (female) private role of domestic nurturer. ${ }^{13}$ Many townspeople visit her house and partake of her hospitality: for instance, the old lady who bought Linda's grandmother visits regularly, and so does the slaveholder's wife who hides Linda before she is moved to the garret of her grandmother's house. Most of all, though, the grandmother's house nourishes and provides refuge for her children, grandchildren, and great-grandchildren. When Linda cannot find enough time to eat properly at Dr. Flint's, she regularly passes her grandmother's 
house when she runs errands: "I was frequently threatened with punishment if I stopped there; and my grandmother, to avoid detaining me, often stood at the gate with something for my breakfast or dinner. I was indebted to her for all my comforts, spiritual and temporal" (19; original emphasis). Linda and her brother William long for a home like their grandmother's. Later, Linda's uncle Phillip, Linda, and Linda's two children live together for a while with Linda's grandmother in her house.

This generational context makes it useful to talk about the temporal aspect of the grandmother's house as chronotope. Biographical time is "quite realistic," according to Bakhtin. "All of its moments are included in the total life process, and they describe this process as limited, unrepeatable, and irreversible" " Bildungsroman" 17-18). Bakhtin refers to biographical novels, but his comments also make sense in relation to the narrative form of Incidents. He explains that

\footnotetext{
[b]iographical life is impossible outside a larger epoch, which goes beyond the limits of a single life, whose duration is represented primarily by generations. . . Generations introduce a completely new and extremely significant aspect into the depicted world; they introduce the contiguity of lives taking place at various times. . . This already provides an entry into historical duration. ("Bildungsroman" 18; original emphasis)
}

The grandmother's house may be seen as the hope of generational continuity in one place. However, the disruptive force of slavery undercuts this hope, this temporal order, which repeatedly breaks up the family.

At various times Linda's grandmother contemplates selling the house in order to buy her son Benjamin and, later, Linda. Benjamin advises her to try to buy his brother Phillip instead, who does not want to go north and leave his mother behind. She manages to do so after a while without selling the house: "She paid eight hundred dollars, and came home with the precious document that secured his freedom. The happy mother and son sat together by the old hearthstone that night, telling how proud they were of each other, and how they would prove to the world that they could take care of themselves, as they had long taken care of others" (43). Here we see the American ideals of self-sufficiency and freedom expressed in a familiar domestic setting, but they take on extended meanings in the voices of exslaves. This scene, evoking a very special sense of exalted motherhood, illustrates the radical, antipatriarchal potential of the discourse of domesticity and shows the grandmother's house as a site of moderate black resistance. The passage refutes with emphasis and irony the antebellum white Southern view of black people as children, incapable of looking after themselves. ${ }^{14}$

The shortcomings of the grandmother's house as shelter, which are tied to the system of slavery, are made evident, for instance, when Linda moves back to her grandmother's house after her first pregnancy is made public. Dr. Flint repeatedly haunts the house, and at times not only verbally but also physically abuses Linda and her son Benny. Once, when the doctor pays one of his unwelcome visits to the grandmother's house, he finds a slave whom he has just sold, which infuriates him. He hits Linda; her grandmother "entered in time to see a second blow dealt. She was not a woman to let such an outrage, in her own house, go unrebuked. . . 'Get out of my house!' she exclaimed. 'Go home' " (125). ${ }^{15}$ Although the doctor does not leave quietly, he does leave and does not come back for the rest of the winter. Despite the limits on her authority in the context of slavery, as the owner of the house and the owner of herself, Linda's grandmother exercises genuine authority at least in her own house.

It has been suggested that the house embodies two entirely distinct sets of propositions: one expressing authority, possession, and dominance; the other weakness, enclosure, and the need for shelter (Danto 9). Both are clearly present in the grandmother's house. However, Linda's narrative shows that the authority and shelter that her grandmother's house provides are severely circumscribed by the national 
political and historical situation. ${ }^{16}$ Despite being close to epitomizing the American middle-class norm, the house and its inhabitants suffer unequal treatment on racial grounds, as exemplified by the intrusion of the search party. Moreover, the conditions of slavery disrupt generational continuity in this house as chronotope. Nevertheless, this chronotope benefits from its embeddedness in the chronotope of the provincial town, which is also connected to the open, communal aspects of the grandmother's house.

\section{The Grandmother's House and Nineteenth-Century American Womanhood}

$\mathrm{F}$ ully understanding the values that the chronotope of the grandmother's house embodies requires comprehending the relation of the characterization of Linda's grandmother to the domestic ideology of the Northern white female addressee. ${ }^{17}$ In the precarious antebellum social world, as Amy Schrager Lang puts it, " ' $[\mathrm{h}]$ ome' . . is something like a projection in space of the woman whose introjection of the virtues associated with the rising middle class-female self-control, domestic privatism, benevolent maternalism, Christian forbearance" (29). In connection with this domestic value system, as Hazel Carby has noted, Jacobs polarizes the qualities of the grandmother and Mrs. Flint. The grandmother is repeatedly "portrayed as a woman of genuine sensitivity" (Carby 56), an efficient housekeeper, and a good mother; Mrs. Flint, in contrast, "like many southern women, was totally deficient in energy. She had not strength to superintend her household affairs; but her nerves were so strong, that she could sit in her easy chair and see a woman whipped, till the blood trickled from every stroke of the lash" (Jacobs 22). On the notice of Dr. Flint's death, Linda observes, "[a]s for Mrs. Flint, I had seen her in deeper afflictions than I supposed the loss of her husband would be, for she had buried several children; yet I never saw any signs of softening in her heart" (294). The lack of sensitivity coupled with deficient or nonexistent domestic and motherly qualities clearly disqualifies her as an ideal antebellum American woman.

The grandmother's characteristics, and through them the values of her house as chronotope, come closer to the Northern ideal of womanhood than to the Southern one. Practical domestic capability was increasingly part of the Northern, more democratic ideal, while in the antebellum South a lady was invariably supposed to have servants. Linda's grandmother, Linda, and her Aunt Nancy are shown to be very competent in the domestic sphere, a trait that would have been recognized and appreciated by the Northern audience. However, the narrator's situation as a domestic servant in the North at the end of the narrative may have complicated her relation to the addressee, since being an employed domestic was not a recommended profession for white middle-class women (Cogan 224).

Conventional motherhood is also represented by the chronotope of the grandmother's house. Republican, Christian motherhood was seen as the mid-nineteenthcentury American woman's most important task: a good mother stayed at home with her children to instruct them and make them good Americans and good Christians (Matthews 7). Although Linda's resolve to escape is firmly grounded in concerns for her children-she hopes that when she is gone Dr. Flint will sell her children to Mr. Sands, whom she believes will then give them their freedomher plan necessarily entails her not being able to watch over them for a while. This strategy means confronting the definition of motherhood embodied by her grandmother's house. The grandmother's response to Linda's plan is to reproach her and encourage her not to leave the children: "Stand by your own children, and suffer with them till death. Nobody respects a mother who forsakes her children; and if 
you leave them, you will never have a happy moment" (139). Thus, based on socially acceptable behavior and motherly feelings, the grandmother, a truly maternal figure both for her own relatives and the larger neighborhood, questions Linda's attempt to save her children by being absent.

Linda also finds it difficult to emulate the piety and trust in God that inform the values of her grandmother's house, and she situates her difficulty on this score in a historical national context. The obstacles that she encounters include the hypocrisy of the church in the South, the un-Christian behavior of many slaveholders including Dr. Flint and his wife, and racist prejudice in the North, not to mention the system of slavery (186). Not until she leaves the United States and goes to England does she receive what she calls "strong religious impressions" (278). She feels entirely free and safe only in England before her employer Mrs. Bruce buys and frees her, because in the United States the North is implicated in the slavery of the South and, as Linda discovers when she arrives there, is thus permeated with racist prejudice.

Still, although at times Linda's grandmother invokes passive endurance and trust in God, she does not stand for passive submission. If she did, she would not be a free woman, the owner of a house, and a provider for children, grandchildren, and a larger community. Linda describes her grandmother as a "woman of a high spirit" who is usually "very quiet in her demeanor; but if her indignation was once roused, it was not very easily quelled." Linda has been told that "she once chased a white gentleman with a loaded pistol, because he insulted one of her daughters" (47). Moreover, the grandmother's leaping up on the auction block is a public act of resistance against Dr. Flint's attempt to use her womanly feelings as an excuse to sell her under the cover of the private sphere; this act of resistance hardly constitutes submission. Neither does throwing the doctor out of her house. As Frances Smith Foster suggests, based on this characterization, the grandmother comes closer to what Frances Cogan calls a Real Woman than to Barbara Welter's description of a True Woman (113). As is well known, Welter declares that the "attributes of True Womanhood, by which a woman judged herself and was judged by her husband, her neighbors, and society, could be divided into four cardinal virtues-piety, purity, submissiveness, and domesticity" (21). Unlike True Womanhood, Real Womanhood, which Cogan argues was a truly Americanized version of womanhood, did not value submissiveness or passivity, but female self-reliance and survival. This, again, would mean that the grandmother would be close to an ideal of womanhood with which the Northern addressee could identify.

The grandmother, then, is suitably situated in a house that as a chronotope seems to represent nineteenth-century American middle-class values, in which the cult of domesticity played an important part. The grandmother's house can therefore be seen as a "comfort zone" for the addressee, a safe place representing values the addressee can share on the condition that she accept, as an example of an ideal woman, the black woman who owns and keeps the house. It is first and foremost with the values that her grandmother's house embodies that Linda needs to negotiate when her sexual liaison with a white man and her pregnancy become public. Linda must also question what being a good mother entails, and in so doing she must confront her grandmother's more conventional view of the subject. Although she appears to respect her grandmother's religious devotion, Linda finds it very difficult to have unconditional faith for a number of reasons that, as I note above, are tied to slavery and racism in the United States. The grandmother's notions of sexual chastity, motherhood, and Christian endurance are depicted as being commendable, perhaps, but they do not help Linda in her trials; and, by exposing the shortcomings of these tenets, Jacobs suggests further revisions of the American ideals of womanhood. However, the grandmother's house is more than simply an American middle-class dwelling. 


\title{
The Garret
}

\begin{abstract}
A ttached to the grandmother's house is a shed above which is the crawlspace or garret where Linda hides for almost seven years before she escapes to the North. The time Linda spends in this garret is foregrounded on the first page of the narrative proper where the title Incidents in the Life of a Slave Girl is repeated, but the comma is followed by the phrase Seven Years Concealed instead of Written by Herself as it says on the title page. ${ }^{18}$ In fact, these seven years constitute a small part of the narrative, which roughly stretches from Linda's becoming aware that she is a slave when she is six years old to her being bought and set free by Mrs. Bruce, her employer in New York, where Linda has spent quite a few years working as a domestic servant. ${ }^{19}$ Linda is astonished when she first hears of the plan to hide her in her grandmother's house: "I could not imagine how it was possible to hide me in her house, every nook and corner of which was known to the Flint family" (75). The garret is actually both part of and not part of the house. Consequently, Gloria T. Randle sees Linda's time in the crawlspace as a mediation between oppositions: "Not only does the garret stand as an unencumbered space between motherlessness and maternal nurturing, but, in a larger sense, it also serves [Linda] as a space between freedom and slavery, childhood and adulthood, motherhood and childlessness, presence and absence, even life and death" (52-53). Georgia Kreiger also reads Linda's "confinement" in the garret as a "liminal position between the living and the dead" (616), which would make it a kind of limbo. Here I discuss the garret as a chronotope that interacts closely with the chronotope of the grandmother's house, although it is not identical with it.

In describing the garret, Jacobs offers the most detailed description of a physical location in the entire book. She places the garret in relation to the rest of the house and comments on both Southern building customs in general and the special concealed trapdoor that her uncle has added to the crawlspace to make it into a hiding place for her. She also provides its exact measurements as well as other uncomfortable and unpalatable features of what will be her home for almost seven years (173). The "factual tone" of the description, as Goddu suggests, emphasizes "Jacobs's refusal to sensationalize her garret" and "reflects her general resistance to the gothic's dematerializing effects" (148). It highlights how little Linda Brent has in common with "the madwoman in the attic" in the nineteenth-century fiction written by white British women that Sandra Gilbert and Susan Gubar examine.

The temporal aspect of this chronotope is very closely connected with changing seasons; that is, cosmological or "natural" time. Consequently, there are many references to how the seasons affect Linda's conditions in the garret.
\end{abstract}

\footnotetext{
Again and again, I thought I should die before long; but I saw the leaves of another autumn whirl through the air, and felt the touch of another winter. In summer the most terrible thunder storms were acceptable, for the rain came through the roof, and I rolled up my bed that it might cool the hot boards under it. Later in the season, storms sometimes wet my clothes through and through, and that was not comfortable when the air grew chilly. Moderate storms I could keep out by filling the chinks with oakum. (183-84)
}

Living in her garret exposes Linda to the seasonal changes almost as relentlessly as the slaves working in the fields at the plantation are exposed, but without having their-albeit restricted-freedom of movement. Nevertheless, she makes it clear that her cramped conditions in the crawlspace are much preferable to her earlier "lot as a slave, though white people considered it an easy one; and it was so compared with the fate of others" (174), and she goes on to enumerate a list of the additional cruelties that could be and were inflicted on other slaves by slaveholders and overseers. Thus, she weighs her exposure to seasonal cycles in a severely circumscribed space 
against the greater evil of slavery with its temporal cycles of oppression and fragmentation, and finds her burden relatively light by comparison.

During Linda's time in the garret, she is acutely aware of the danger to which she exposes her relatives and the house: "Had the least suspicion rested on my grandmother's house, it would have been burned to the ground" (177). To avoid suspicion, her grandmother cunningly invites two people for Christmas dinner: "One was the town constable, and the other was a free colored man, who tried to pass himself off for white, and who was always ready to do any mean work for the sake of currying favor with white people" (181). The grandmother manages to show them the whole house. Here the openness of the grandmother's household is used to deceive slave hunters. The architectonic doubleness with its hidden garretits concealment within openness, its fugitive slave hidden within middle-class comfort, the black owner pretending to show white authorities everything there is to be seen-makes it into what I think can be called a double-voiced structure. ${ }^{20}$ It graphically illustrates African American "dissembling." 21 This scene can also be said to chronotopically flesh out, and sum up, Jacobs's scathing critique of antebellum American society: the impossible contradiction of the existence of slavery in an allegedly progressive, enlightened, democratic society.

Linda also practices cunning to delude her enemy, Dr. Flint: "She uses her garret cell as a war room from which to spy on her enemy and to wage psychological warfare against him. ... [S]he manipulates the sale of her children to their father, arranges for her daughter to be taken north, tricks her master into believing that she has left the South" (Yellin, Introduction xxviii). In chapter 25, which is aptly called "Competition in Cunning," Jacobs describes how Linda tricks Dr. Flint; she writes deceptive letters representing herself as being in the North and sends them with other people to be mailed from there. Her grandmother is "sadly troubled" by these stratagems and does not appreciate the "comedy" of Dr. Flint's believing in the authenticity of Linda's letters or feel right when lying about their contents $(194,197)$. She is afraid that the doctor will force Phillip to go north to fetch Linda, and that nothing good will ever come of her shrewd letter game. Linda says later, "I like a straightforward course, and am always reluctant to resort to subterfuges. So far as my ways have been crooked, I charge them all upon slavery. It is that system of violence and wrong which now left me no alternative but to enact a falsehood" (251).

Thus the chapter "Competition in Cunning" reveals the tension between the grandmother's house as a chronotope embodying mid-nineteenth-century ideal womanhood and Linda's "war headquarters" - the garret. Although the grandmother is willing to "enact a falsehood" to protect Linda, she is much more cautious and conservative than her granddaughter, who actually appears to appreciate actively engaging in a battle of minds with Dr. Flint when her predicament warrants it. As a concerned true mother, the grandmother's anxiety for her children-including Linda-nearly prevents Linda's escape to the North. The grandmother's love, like Sethe's in Toni Morrison's Beloved, is almost too thick and protective, and it threatens to turn Linda's garret into something even more like a prison cell than it already is. Later, facing her situation in the North after her daughter Ellen leaves for boarding school, Linda shows greater flexibility: "It required a great effort for me to consent to part with her, for I had few near ties, and it was her presence that made my two little rooms seem home-like. But my judgment prevailed over my selfish feelings" (282). It is fair to point to the difference in age and experience between Linda and her grandmother, but I still find that the grandmother has a less flexible idea of motherhood than Linda, who repeatedly expresses her wish to be a good mother but realizes that this means constant negotiations with norms and prescribed ideals in situated contexts.

After being confined in it for almost seven years, Linda leaves the garret with ambivalent feelings: 
For the last time I went up to my nook. Its desolate appearance no longer chilled me, for the light of hope had risen in my soul. Yet, even with the blessed prospect of freedom before me, I felt very sad at leaving forever that old homestead, where I had been sheltered so long by the dear old grandmother; where I had dreamed my first young dream of love; and where, after that had faded away, my children came to twine themselves so closely round my desolate heart. (235)

It should be noted here that her emotional ambivalence in this instance arises from the tension between the two chronotopes: the garret and the grandmother's house, the desolate nook and the "old homestead."

Linda never refers to the garret in positive terms: although it keeps her out of the grasp of Dr. Flint and works as a site of resistance in her "war" against him, in many ways it epitomizes a slave's unsheltered and restricted conditions. Physically impaired by lack of space and exercise, exposed to seasonal changes and the monotony and boredom of a seemingly unending confinement, she finds herself separated from her children and from a normal life with her relatives and friends. The grandmother's house, on the other hand, represents shelter, nourishment, youthful dreams of marrying a respectable free black man, and motherhood. Indeed, it is precisely in the multifaceted interrelationship of these two chronotopes that Jacobs exposes the contradictions of slavery, contradictions that generate a "dismal hole," a "dungeon," in the middle of domestic comfort $(224,210)$.

The chronotope, then, is a useful concept through which to read the relations between spaces, temporalities, genre conventions, characterization, and ideology in Harriet Jacobs's Incidents in the Life of a Slave Girl. It brings together central concerns of researchers, such as Gleason, English, and Pratt, who have recently examined a range of aspects of race, architecture, time, justice, and genre in nineteenth-century African American literature. Focusing on the complex interactions within and between the four chronotopes-Dr. Flint's house, the provincial town, the grandmother's house, and the garret_-yields a deeper understanding of how Jacobs employs sophisticated narrative strategies to reach and negotiate with her white Northern audience, while at the same time severely criticizing the limited access to as well as the limitations of the American ideology of domesticity for African Americans in general, and women slaves in particular. African American domestic deprivations, Incidents illustrates, are part of an even larger political problem for the nation: the United States of the mid-nineteenth century was subsumed in its entirety by the chronotope of slavery.

1. An earlier version of this text, with a slightly different focus, was printed as part of a chapter in my dissertation. In the chapter, "Cramped Conditions," I argue for the centrality of the grandmother's house as chronotope (including the chronotope of the garret) in the narrative, and I end the chapter by discussing the construction of the first-person narrator as a public "I." See Maria Holmgren Troy, "In the First Person and in the House: The House Chronotope in Four Works by American Women Writers," Diss. (Uppsala U, 1999), 52-93.

2. With the help of Jacobs's letters, Yellin managed to establish the actual names of Southern places and people figuring under fictitious names in Incidents, proving that Harriet Jacobs is indeed the author of the narrative. See also Farah Jasmine Griffin, Introduction to Incidents in the Life of a Slave Girl Written by Herself, by Harriet Jacobs (New York: Barnes \& Noble, 2005), xxii-xxiii.

3. Wolfe argues that Incidents is double-voiced: in addition to addressing a white female Northern audience, "Jacobs sends the message to Northern blacks that they must prepare to fight for their rights as human beings who are equal to their white neighbors" (518). Foreman elegantly forwards a similar, but more complex, argument by coining and employing the term "simultextual": "Like the other writings I examine in Activist Sentiments, Incidents is characterized by a narrative plentitude that reaches various audiences" (42). In this article, however, I focus on Incidents' communication-through the employment of chronotopes - with nineteenth-century Northern white women readers. 
4. Foster, among others, sees "incidents" in the title as a sign of Jacobs's control of her narrative through careful selection (108). Greeson argues that Jacobs draws on the episodic plot scheme of urban gothic tales rather than the more "politically conservative seduction plot" used in "tragic mulatta" stories by, for instance, Harriet Beecher Stowe and William Wells Brown (292). The point Greeson makes is that the typical episodic urban gothic plot shows systematic abuse rather than the abuse perpetuated by a "depraved individual" (292). Both Foster's and Greeson's discussions were published quite some time before Albert H. Tricomi's thorough investigation into the extent of the editor Lydia Maria Child's changes and contributions to Jacobs's narrative. Tricomi argues that it is more likely that Child, rather than Jacobs, named the narrative Incidents in the Life of a Slave Girl. He also shows that some of the nonlinear disruptions of the narrative are the editor's rather than the author's. See Tricomi, "Harriet Jacobs's Autobiography and the Voice of Lydia Maria Child," ESQ 53.3 (2007): 216-52.

5. Randle also mistakes Dr. Flint's house for a plantation (51). Indeed, at one point, she seems to mistake the entire small town for a plantation: "Brent's grandmother is a freed slave who remains on the plantation" (45). I argue that the differences between Dr. Flint's house in town, the small provincial town, and a plantation are highly significant to Linda's situation as well as the reader's understanding of her and her situation.

6. For critical discussions that address the limits of Linda's sexual agency and consent, see Foreman and Saidiya Hartman, Scenes of Subjection: Terror, Slavery, and Self-Making in Nineteenth-Century America (New York: Oxford UP, 1997).

7. As Gleason points out in his discussion of Crafts's narrative, "Complete self-ownership . . . requires homeownership" (44). In an excellent article, Warner argues that, in Incidents, Jacobs "constructed for her northern readers a radically new portrait of a southern home," and "Jacobs' home- such an important theme in her narrative - remained, in significant ways, the home of her grandmother ... to which she could not foresee a return while slavery existed" (30).

8. In a letter to Jacobs dated August 13,1860, Child writes, "My object in writing at this time is to ask you to write what you can recollect of the outrages committed on the colored people, in Nat Turner's time" (Incidents, Yellin, ed. 244).

9. Harriet Beecher Stowe discusses this class of people under the heading "Poor White Trash" in her Key to Uncle Tom's Cabin (1853): "This miserable class of whites form, in all the Southern States, a material for the most horrible and ferocious of mobs. Utterly ignorant, and inconceivably brutal, they are like some blind, savage monster, which, when aroused, tramples heedlessly over everything in its way." Stowe also notes, "The leaders of the community . . . keep this blind furious monster of the MOB, very much as an overseer keeps plantation-dogs" (451). Stowe obviously uses gothic vocabulary to discuss this class of Southern whites that the system of slavery has produced, and she also observes that the masters who unleash the mob (the "brute monster") sometimes lose control of it (452).

10. For a discussion of Northern antebellum class conflicts and middle-class attitudes toward the poor, see Diana Loercher Pazicky, Cultural Orphans in America (Jackson: UP of Mississippi, 1998), 118-48. Lang concludes, in The Syntax of Class: Writing Inequality in Nineteenth-Century America, that "[t]he reforming middle class, with its deep fear of class conflict, its obsessive concern with self-control, and its devotion to 'home-in the better sense' as a figure of social harmony, shaped, in large measure, the literary syntax of class in mid-nineteenth-century America" (129). I would suggest that Jacobs draws on this literary syntax to communicate with her white female middle-class readers.

11. Jacobs's description of the Johnkannaus festivities certainly refutes any claims of lower-class plantation slaves' total degradation and brutalization, and in this she invalidates stereotypical representations of slaves that were used by both pro- and antislavery writers at the time when she wrote the narrative. For discussions of how Jacobs describes and employs the celebration of Johnkannaus in Incidents, see Warner 40-43 and Wolfe 522-23. Both Warner and Wolfe contrast Jacobs's depiction of this carnivalesque-but orderly and sober - celebration to Frederick Douglass's "degrading depiction of slave holiday traditions" (Wolfe 522).

12. Gomaa sees "home" in Incidents and Harriet Wilson's Sketches as a trope related to the slave woman's body: "body as home" (372). She asserts that "[h]omelessness communicates a universal feeling of vulnerability, but at the same time it ties this feeling to the particular ways in which black women experienced a profound homelessness" (372), and when Jacobs "regrets the loss of virginity . .., she is essentially regretting the loss of home" (377).

13. Peterson makes a similar observation: "Brent's grandmother's house illustrates how the AfricanAmerican domestic sphere is neither private nor public but generates an in-house economy in which children are sheltered, goods produced, and the community taken care of" (159).

14. As Warner puts it, Jacobs "re-present[s] the ethos of the African American family and home in the South. Incidents is the antidote to . . . pictures of slaves as mindless and carefree children, unconcerned with an orderly existence and incapable of serious, self-motivated productivity. [Nathaniel Parker] Willis, 
[Amelia Matilda] Murray, and even Stowe help to perpetuate these reductive and demeaning types, and Jacobs responds by rectifying these 'fictional' images" (33).

15. Fulton argues that "On one level, Black feminist orality can be understood as related to the African American women's tradition of 'sass' in which one responds with independence, knowing, and force to an individual in authority" (13). At more than one point in Incidents, the illiterate grandmother is a forceful user of black feminist orality.

16. See Rifkin for a brilliant article on how Incidents engages with national politics and African American activist discourse through its depiction of frustrated black domesticity: "scenes of trespass into black domestic spaces demonstrate that the security of putatively private property depends on the possession of a range of civic entitlements" (86).

17. An antipatriarchal-but not necessarily feminist or radical-ideology, the discourse or cult of domesticity provided a framework in which nineteenth-century white women could think about their world and possibly improve it. See Lora Romero, Home Fronts: Domesticity and Its Critics in the Antebellum United States (Durham: Duke UP, 1997), 19-20. Yet this ideology was fraught with contradictions, obscuring class difference and drawing attention away from the intensified construction of racial difference. See Kathleen Anne McHugh, American Domesticity: From How-to Manual to Hollywood Melodrama (New York: Oxford UP, 1999), 35-36. Privileging gender difference, the discourse of domesticity ignored the racialization of women's possibilities and agency.

18. Yellin left out the phrase "Seven Years Concealed" in her 1987 edition of Incidents, but it appears in the Schomburg Library of Nineteenth-Century Black Women Writers edition (1988) and in Henry Louis Gates, Jr.'s edition of Classic Slave Narratives (1987). According to the publisher's note in the Schomburg edition, "[w]henever possible, the volumes in this set were reproduced from original materials."

19. The time Linda spends in the crawlspace occupies only nine chapters out of the narrative's forty-one (173-236). She moves into the garret in the twenty-first chapter, "The Loophole of Retreat." Burnham describes this chapter at the dead center of the narrative as "the hinge which balances twenty chapters on either side" (53). Kreiger calls Linda's time in the garret "the narrative's central event" and "extended turning point" $(607,609)$, and argues that death is an important "metaphor for Brent's experience in hiding" (607).

20. The notion of double-voiced words and utterances is of course Bakhtin's, but even more helpful here is Gates's elaboration on Bakhtin's concept in an African American context in The Signifying Monkey: "Signifyin(g) is black double-voicedness" (51). It is the word or utterance "decolonized for the black's purposes "by inserting a new semantic orientation into a word which already has - and retains - its own orientation' " (Gates 50). For an article that uses Gates to discuss double-voicedness in Incidents, see Wolfe.

21. "Whether possessed of book learning or not, the dissembling slave was a confidence figure who displayed a profound consciousness of language, created a space for the expression of his or her will or identity, and seized the opportunity to escape" (Smith 5).

Bakhtin, M. M. "The Bildungsroman and Its Significance in the History of Realism (Toward a Historical Typology of the Novel)." Speech Genres and Other Late Essays. Ed. Caryl Emerson and Michael Holquist. Trans. Vern W. McGee. Austin: U of Texas P, 1986. 10-59.

--. "Forms of Time and of the Chronotope in the Novel." The Dialogic Imagination. Ed. Michael Holquist. Trans. Caryl Emerson and Michael Holquist. Austin: U of Texas P, 1990. 84-258.

Burnham, Michelle. "Loopholes of Resistance: Harriet Jacobs' Slave Narrative and the Critique of Agency in Foucault." Arizona Quarterly 49.2 (1993): 53-73.

Carby, Hazel V. Reconstructing Womanhood: The Emergence of the Afro-American Woman Novelist. Oxford: Oxford UP, 1987.

Cogan, Frances B. All-American Girl: The Ideal of Real Womanhood in Mid-Nineteenth-Century America. Athens: U of Georgia P, 1989.

Danto, Arthur C. "Abide/Abode." Housing: Symbol, Structure, Site. Ed. Lisa Taylor. New York: CooperHewitt Museum, 1990. 8-9.

English, Daylanne K. Each Hour Redeem: Time and Justice in African American Literature. Minneapolis: U of Minnesota P, 2013.

Foreman, P. Gabrielle. Activist Sentiments: Reading Black Women in the Nineteenth Century. Urbana: U of Illinois P, 2009.

Foster, Frances Smith. Written by Herself: Literary Production by African American Women, 1746-1892. Bloomington: Indiana UP, 1993.

Fulton, DoVeanna S. Speaking Power: Black Feminist Orality in Women's Narratives of Slavery. Albany: SUNY P, 2006. 
Gates, Henry Louis, Jr. The Signifying Monkey: A Theory of African-American Literary Criticism. New York: Oxford UP, 1988.

Gilbert, Sandra M., and Susan Gubar. The Madwoman in the Attic: The Woman Writer and the NineteenthCentury Literary Imagination. New Haven: Yale UP, 1979.

Gleason, William A. Sites Unseen: Architecture, Race, and American Literature. New York: New York UP, 2011.

Goddu, Teresa A. Gothic America: Narrative, History, and Nation. New York: Columbia UP, 1997.

Gomaa, Sally. "Writing to 'Virtuous' and 'Gentle' Readers: The Problem of Pain in Harriet Jacobs's Incidents and Harriet Wilson's Sketches.” African American Review 43.2-3 (2009): 371-81. Academic Search Elite. Web. 26 Jan. 2013.

Greeson, Jennifer Rae. "The 'Mysteries and Miseries' of North Carolina: New York City, Urban Gothic Fiction, and Incidents in the Life of A Slave Girl." American Literature 73.2 (2001): 277-309. Academic Search Elite. Web. 26 Jan. 2013.

Jacobs, Harriet. Incidents in the Life of a Slave Girl. 1861. Oxford: Oxford UP, 1988.

Keizer, Arlene R. Black Subjects: Identity Formation in the Contemporary Narrative of Slavery. Ithaca: Cornell UP, 2004.

Kreiger, Georgia. "Playing Dead: Harriet Jacobs's Survival Strategy in Incidents in the Life of a Slave Girl." African American Review 42.3-4 (2008): 607-21. Academic Search Elite. Web. 26 Jan. 2013.

Lang, Amy Schrager. The Syntax of Class: Writing Inequality in Nineteenth-Century America. Princeton: Princeton UP, 2003.

Levy, Andrew. "Dialect and Convention: Harriet A. Jacobs's Incidents in the Life of a Slave Girl." Nineteenth-Century Literature 45.2 (1990): 206-19.

Matthews, Glenna. "Just a Housewife": The Rise and Fall of Domesticity in America. Oxford: Oxford UP, 1987.

Peterson, Carla L. "Doers of the Word": African-American Women Speakers and Writers in the North (1830-1880). Oxford: Oxford UP, 1995.

Pratt, Lloyd. Archives of American Time: Literature and Modernity in the Nineteenth Century. Philadelphia: U of Pennsylvania P, 2010.

Randle, Gloria T. "Between the Rock and the Hard Place: Mediating Spaces in Harriet Jacobs's Incidents in the Life of a Slave Girl." African American Review 33.1 (1999): 43-56. Academic Search Elite. Web. 26 Jan. 2013.

Rifkin, Mark. “'A Home Made Sacred by Protecting Laws': Black Activist Homemaking and Geographies of Citizenship in Incidents in the Life of a Slave Girl." differences 18.2 (2007): 72-102. Academic Search Elite. Web. 26 Jan. 2013.

Smith, Valerie. Self-Discovery and Authority in Afro-American Narrative. Cambridge: Harvard UP, 1987.

Stowe, Harriet Beecher. A Key to Uncle Tom's Cabin. $2^{\text {nd }}$ ed. London: Sampson Low, Son, 1853.

Warner, Anne Bradford. "Harriet Jacobs at Home in Incidents in the Life of a Slave Girl." Southern Quarterly 45.3 (2008): 30-47. Academic Search Elite. Web. 26 Jan. 2013.

Welter, Barbara. Dimity Convictions: The American Woman in the Nineteenth Century. Athens: Ohio UP, 1976.

Wolfe, Andrea Powell. "Double-Voicedness in Incidents in the Life of a Slave Girl: 'Loud Talking' to a Northern Black Readership." American Transcendental Quarterly 22.3 (2008): 517-25. Academic Search Elite. Web. 26 Jan. 2013.

Yellin, Jean Fagan. Introduction. Incidents in the Life of a Slave Girl Written by Herself. By Harriet A. Jacobs. Ed. Jean Fagan Yellin. Cambridge: Harvard UP, 1987. xiii-xxxiv.

--. "Written by Herself: Harriet Jacobs' Slave Narrative." American Literature 53.3 (1981): 479-86. 
Copyright of African American Review is the property of African American Review and its content may not be copied or emailed to multiple sites or posted to a listserv without the copyright holder's express written permission. However, users may print, download, or email articles for individual use. 